\title{
PARAMPHISTOMUM DAUBNEYI: CHARACTERISTICS OF INFECTION IN THREE LYMNAEID SPECIES
} SANABRIA R.*, TITI A.**, MEKROUD A.**, VIGNOLES P.***, DREYFUSS G.***, RONDELAUD D.*** \& ROMERO J.*

\section{Summary:}

Experimental infections of two South American lymnaeids (Lymnaea neotropica and $L$. viatrix var. ventricosa) with Paramphistomum daubneyi were carried out to determine if these snail species could sustain larval development of this digenean and, if so, to specify their potential for cercarial production. A French population of Galba truncatula infected and raised according to the same protocol served as controls. In both experiments, prevalence of P. daubneyi infections in snails did not significantly differ from each other. In snail groups evaluated for cercarial shedding (first experiment), a significantly lower number of shed cercariae was noted for $L$. neotropica, while those from $G$. truncatula and $L$. $V$. ventricosa did not differ significantly from each other. Dissection of infected snails at day 65 post-exposure at $20^{\circ} \mathrm{C}$ (second experiment) found significantly lower burdens of $P$. daubneyi rediae and cercariae in the bodies of $L$. neotropica than in those of $G$. truncatula and L. v. ventricosa. Compared to total cercarial production observed in dissected snails, the percentage of cercariae which exited from snails was $75.6 \%$ for G. truncatula, $21.6 \%$ for $L$. neotropica, and $91.4 \%$ for $L$. v. ventricosa. This last species seems to be a good candidate for metacercarial production of $P$. daubneyi.

KEY WORDS: Galba truncatula, Lymnaea neotropica, Lymnaea viatrix, Paramphistomum daubneyi, experimental infection, metacercaria, redia.
Résumé : PARAMPHISTOMUM DAUBNEYI : CARACTÉRISTIQUES DE L'INFESTATION CHEZ TROIS ESPÈCES DE LIMNÉES

Des infestations expérimentales de deux limnées sud-américaines (Lymnaea neotropica et $\mathrm{L}$. viatrix var. ventricosa) avec Paramphistomum daubneyi ont été réalisées pour déterminer si ces espèces peuvent assurer le développement larvaire de ce Digène et, dans l'affirmative, pour préciser leur potentiel dans la production cercarienne. Les témoins sont constitués par une population française de Galba truncatula infestée et élevée selon le même protocole. Dans les deux expériences, les prévalences de l'infestation par P. daubneyi chez les mollusques sont proches les unes des autres. Chez les groupes suivis pour les émissions cercariennes (première expérience), le nombre de cercaires émises est significativement plus faible chez L. neotropica, tandis que les chiffres notés chez $\mathrm{G}$. truncatula et $\mathrm{L}$. v. ventricosa ne présentent pas de différence significative. Si les mollusques infestés sont disséqués au $65^{\text {ème }}$ jour post-exposition à $20^{\circ} \mathrm{C}$ (seconde expérience), les charges rédienne et cercarienne trouvées dans le corps des L. neotropica sont significativement plus faibles que celles notées chez G. truncatula et L. v. ventricosa. Par rapport à la production cercarienne totale chez les mollusques disséqués, le pourcentage de cercaires qui sont émises est de 75,6 \% chez G. truncatula, 21,6 \% chez L. neotropica et de 91,4\% chez L. v. ventricosa. Cette dernière espèce semble être un bon candidat pour la production métacercarienne de P. daubneyi.

MOTS-CLÉS : Galba truncatula, Lymnaea neotropica, Lymnaea viatrix, Paramphistomum daubneyi, infestation expérimentale, métacercaire, rédie.

Europe, the main snail host is Galba truncatula (Sey, 1979; Brown, 1994). However, other European lymnaeids such as Omphiscola glabra, Stagnicola fuscus and S. palustris (Abrous et al., 1998; Degueurce et al., 1999) may support larval development of $P$. daubneyi if they have been co-infected with another digenean, Fasciola hepatica. Under these conditions, snails may harbour larval forms of the first parasite, the second, or both (Rondelaud et al., 2009).

The aim of the present paper was to identify lymnaeids other than European species, which may act as intermediate hosts in the life cycle of $P$. daubneyi. Due to the global distribution of this digenean (see above), we chose amphibious lymnaeids from South America for the following two reasons: $i$ ) numerous cattle and other animals were introduced to this continent in the $16^{\text {th }}$ century by Spanish and Portuguese (Mas-Coma et al., 2009); and ii) the paramphistomid 
currently present in cattle from Spain and Portugal is P. daubneyi (Diaz et al., 2007; Arias et al., 2011). Experimental infections of two South American lymnaeids: Lymnaea neotropica and L. viatrix var. ventricosa with a French isolate of $P$. daubneyi miracidia were thus carried out to determine their capacity to sustain the development of larval forms and to specify the quantity of $P$. daubneyi cercariae these snail species might produce when the method proposed by Rondelaud et al. (2007) for amphibious snails was used for their breeding. Controls came from a French population of $G$. truncatula infected and raised according to the same protocol.

\section{MATERIAL AND METHODS}

T The two South American lymnaeids have been raised under laboratory conditions at CEDIVE (Faculty of Veterinary Sciences, National University of La Plata, Buenos Aires, Argentina) since 2008 (L. neotropica) and 1996 (L. v. ventricosa). The first species came from a population living in San Pedro, Buenos Aires, Argentina ( $33^{\circ} 40^{\prime}$ S, $59^{\circ} 39^{\prime}$ W), while L. v. ventricosa originated from Paysandú, Uruguay $\left(36^{\circ} 00^{\prime} \mathrm{S}, 57^{\circ} 30^{\prime} \mathrm{W}\right)$. As the systematics of South American lymnaeids is controversial and cannot be done with the use of single morphological criteria (Duffy et al., 2009; Mera y Sierra et al., 2009), the identification of these two species was performed using PCR-RFLP and sequencing of the ITS-1 segment of their nuclear rDNA (Sanabria et al., 2012). The French population of $G$. truncatula was collected from a road ditch ( $\left.45^{\circ} 55^{\prime} 33^{\prime \prime} \mathrm{N}, 2^{\circ} 2^{\prime} 33^{\prime \prime} \mathrm{E}\right)$ in the commune of Saint-Michel-de-Veisse, department of Creuse. The habitat of this last population was located on siliceous soil so that the upper shell height of adults (8-9 mm) was the same as that of South American adults. To obtain P. daubneyi eggs, adult worms were collected from the rumen of infected cattle at the slaughterhouse of Limoges (France) and dipped in a physiological saline ( $\mathrm{ClNa}, 0.9 \%$; glucose, $0.45 \%$ ) solution before being placed at $37{ }^{\circ} \mathrm{C}$ for three hours. Eggs were washed several times with spring water and incubated at $20{ }^{\circ} \mathrm{C}$ in the dark according to the report by Ollerenshaw (1971) for $F$. hepatica.

Two experiments were carried out in the present study. The aptitude of each snail species as an intermediate host of $P$. daubneyi was studied in experiment (A). One hundred snails, each measuring $4 \mathrm{~mm}$ in height, were randomly chosen from each population and subjected to individual quadrimiracidial exposures for four hours at $20^{\circ} \mathrm{C}$. The choice of four miracidia per snail came from the results of a preliminary experiment with these three populations and routine bimiracidial infections. Under these conditions, $3.2 \%$ and $6.1 \%$ of L. neotropica and $L . v$. ventricosa, respectively, were infected (instead of $91.8 \%$ of G. truncatula) but most snails died without cercarial shedding (unpublished data). Snails were then raised in groups of ten individuals in $14 \mathrm{~cm}$ Petri dishes during the first 30 days according to the method of Rondelaud et al. (2007). They were maintained on dried lettuce leaves and dead grass leaves (Molinia caerulea), while several stems of live Fontinalis sp. ensured oxygenation of the water layer. Petri dishes were placed at a constant temperature of $20^{\circ} \mathrm{C}$ $\left( \pm 1^{\circ} \mathrm{C}\right)$, with a natural photoperiod of ten hours light. At day 30 post exposure (p.e.), each surviving snail was placed in a $35 \mathrm{~mm}$ Petri dish with pieces of dead grass, lettuce and spring moss, and also kept at $20^{\circ} \mathrm{C}$. Snails were observed daily to change spring water and food if necessary, and to count metacercariae before their removal from dishes. When the first cercarial shedding occurred, the surviving snails were subjected to a thermal shock every three days by placing their Petri dishes at $10-13{ }^{\circ} \mathrm{C}$ for three hours (outdoors) to stimulate cercariae exit. Experiment (B) was carried out on order to determine cercarial production of $P$. daubneyi in snails dissected at day 65 p.e. at $20^{\circ} \mathrm{C}$ (the first cercarial shedding generally occurred at the end of week 9 p.e.). Each experimental group contained 50 snails. Snail exposure to miracidia and their breeding were similar to those of experiment (A). At day 65, each snail was dissected under a stereomicroscope to count free white procercariae and yellowish brown cercariae of $P$. daubneyi. Free rediae were also taken into account.

The first two parameters were snail survival at day 30 p.e. and prevalence of $P$. daubneyi infection (calculated in relation to the number of surviving snails at day 30 p.e.). Prevalence took into account the number of cercariae-shedding snails (CS snails) and infected individuals, which died without cercariae exit (NCS snails) in experiment (A), and all snails carrying larval forms of $P$. daubneyi in experiment (B). For each parameter, the difference between the values noted for the three snail groups was analyzed using a $\chi^{2}$ test. In experiment (A), the growth of CS snails during the experiment, length of the prepatent period, length of the patent period, and total number of metacercariae were also taken into account. In experiment (B), the number of free rediae, quantity of procercariae and that of free cercariae were considered. Individual values recorded for these last seven parameters were averaged and their standard deviations calculated considering snail groups. One-way analysis of variance was used to establish levels of significance. All statistics were made using Statview 5.0 software. 


\section{RESULTS AND DISCUSSION}

C ompared to the survival of control G. truncatula at day 30 p.e. (Table I), the rate of L. neotropica was significantly greater while that of L. v. ventricosa was lower $\left(\chi^{2}=11.50, P<0.01\right)$. The differences between prevalence of infection, growth of CS snails, lengths of prepatent periods, and those of patent periods were insignificant. In contrast, the number of metacercariae shed by L. neotropica was significantly lower $(F=4.70, P<0.05)$ than those released by the other two lymnaeids. Contrary to $G$. truncatula, which shed its cercariae during several waves, most $L$. neotropica and L. v. ventricosa released these larvae during a single shedding wave and died after (data not shown).

Table II gives the results of experiment (B). Significant differences $\left(\chi^{2}=18.05, P<0.001\right)$ were noted between the survival of G. truncatula at day 30 p.e. and the rates of the other two lymnaeids. As for experiment (A), prevalence of $P$. daubneyi infection in the three snail groups did not differ significantly from each other. Significantly lower numbers of free rediae $(F=$ 4.26, $P<0.05)$ and free cercariae $(F=3.58, P<0.05)$ were seen for $L$. neotropica, whereas the differences existing between the other two lymnaeids were insignificant. In all three snail groups, the numbers of free procercariae were similar and no significant difference was noted.

If the number of shed cercariae (Table I) was compared to total cercarial production within the snail body (Table II), the percentage of larvae which exited from the snail was $75.6 \%$ for G. truncatula and $91.4 \%$ for $L$. v. ventricosa, while it was only $21.6 \%$ for $L$. neotropica.

As the intermediate hosts of $P$. daubneyi in Africa and Europe are G. truncatula and Lymnaea peregra (Sey, 1979), the findings reported in the present study demonstrated that $L$. neotropica and $L$. $v$. ventricosa also were potential snail hosts for this digenean. Two perhaps complementary hypotheses may be proposed to explain these results. First, P. daubneyi is apparently present in South America, at least in Argentina and Uruguay, even though other paramphistomids such as Paramphistomum cervi (Nascimento et al., 2006) and Paramphistomum leydeni (Sanabria et al., 2011a, b) have already been reported on this continent. Secondly, larval development of $P$. daubneyi might occur in several species of the genus Galba/Fossaria. An argument supporting this last approach was the

\begin{tabular}{|c|c|c|c|}
\hline Parameters & G. truncatula & L. neotropica & L. v. ventricosa \\
\hline Number of preadult snails at exposure & 100 & 100 & 100 \\
\hline Number of surviving snails at day 30 p.e. (survival rate \%) & $68(68.0)$ & $81(81.0)$ & $59(59.0)$ \\
\hline Number of CS snails & 25 & 34 & 16 \\
\hline Number of NCS snails & 11 & 7 & 7 \\
\hline Prevalence of infection (\%) & 52.9 & 50.6 & 54.5 \\
\hline Growth of CS snails during the experiment (mm)* & $2.7(0.6)$ & $2.6(0.8)$ & $2.7(0.7)$ \\
\hline \multicolumn{4}{|l|}{ Length (days)*: } \\
\hline - prepatent period & $69.3(3.1)$ & $73.1(4.6)$ & $71.5(2.9)$ \\
\hline - patent period & $24.8(1.9)$ & $27.6(6.0)$ & $25.0(8.5)$ \\
\hline Total number of metacercariae* & $169.2(76.1)$ & $37.4(25.2)$ & $253.0(151.2)$ \\
\hline
\end{tabular}

* Mean value (S.D.); CS snails, cercariae-shedding snails; NCS, infected snails without cercarial shedding

Table I. - Main characteristics of $P$. daubneyi infection in three species of lymnaeid snails (experiment A).

\begin{tabular}{lccc}
\hline \multicolumn{1}{c}{ Parameters } & G. truncatula & L. neotropica & L. v. ventricosa \\
\hline Number of preadult snails at exposure & 50 & 50 & 50 \\
Number of surviving snails at day 30 p.e. (survival rate \%) & $37(74.0)$ & $45(90.0)$ & $26(52.0)$ \\
Number of snails containing cercariae (prevalence \%) & $19(51.3)$ & $22(48.8)$ & $13(50.0)$ \\
Number of free rediae* & $34.4(5.1)$ & $26.2(8.6)$ & $39.5(6.2)$ \\
Number of free procercariae* & $81.4(21.0)$ & $62.5(15.6)$ & $99.5(29.9)$ \\
Number of free cercariae* & $142.4(32.3)$ & $110.2(27.4)$ & $177.3(52.9)$ \\
Total cercarial production* & $223.8(27.3)$ & $172.7(21.8)$ & $276.8(37.1)$ \\
\hline
\end{tabular}

* Mean value (S.D.).

Table II. - Counts of $P$. daubneyi rediae and cercariae in three species of lymnaeids at day 65 p.e. at $20^{\circ} \mathrm{C}$ (experiment B). 
report by Castro-Trejo et al. (1990) with $P$. cervi larvae developing in three lymnaeids (Lymnaea cubensis, $L$. bumilis and L. palustris).

In the two South American lymnaeids, there was a strong disparity in snail response to larval development of P. daubneyi. Compared to control G. truncatula, the mean redial and cercarial burdens in $L . v$. ventricosa (Table II) were slightly higher and this snail population shed $91.4 \%$ of its cercariae. In contrast, in $L$. neotropica, redial and cercarial burdens were significantly lower (Table II) and only $21.6 \%$ of cercariae were shed. These findings may be interpreted as consequences of a still incomplete adaptation between both partners and this incomplete adaptation would be greater for $L$. neotropica than for L. v. ventricosa. This hypothesis is supported by the fact that numerous South American lymnaeids shed their cercariae during a single wave. According to Rondelaud et al. (2009), the exit of $F$. hepatica cercariae during a single wave of one or several days, followed by snail death, indicated an incomplete adaptation between snail population and the parasite.

Low lengths of patent periods were noted for infected L. neotropica and L.v. ventricosa in the present study. In contrast, longer patent periods up to a mean of 96.3 days for $L$. v. ventricosa, for example, infected by Fascioloides magna (Sanabria et al., 2012) were reported. As control G. truncatula also showed low lengths of patent periods (Table I), these findings can be explained by the use of four miracidia per snail.

\section{CONCLUSION}

$\mathrm{E}$ ven if the miracidial burden of $P$. daubneyi used in the present study seemed to clearly reduce life expectation of infected $L . v$. ventricosa, this species is a good candidate for metacercarial production of this digenean. As breeding of this snail in the laboratory using the method by Rondelaud et al. (2007) was easier than for G. truncatula, this lymnaeid might replace $G$. truncatula as a snail host for $P$. daubneyi. However, a study on the viability of metacercariae produced by $L . v$. ventricosa and their development into adults in the definitive host is still necessary to optimize the characterization of this snail species.

\section{REFERENCES}

Abrous M., Rondelaud D., Dreyfuss G. \& Cabaret J. Unusual transmission of the liver fluke, Fasciola hepatica, by Lymnaea glabra or Planorbis leucostoma in France. Journal of Parasitology, 1998, 84, 1257-1259.
Arias M., lomba C., Dacal V., Vázquez L., Pedreira J., Francisco I., Piñeiro P., Cazapal-Monteiro C., Suárez J.L., DiezBaños P., Morrondo P., SÁnchez-Andrade R. \& Paz-Silva A. Prevalence of mixed trematode infections in an abattoir receiving cattle from northern Portugal and north-west Spain. The Veterinary Record, 2011, 168, 408.

Castro-Trejo L., Garcia-Vazquez Z. \& Casildo-Nieto J. The susceptibility of lymnaeid snails to Paramphistomum cervi infections in Mexico. Veterinary Parasitology, 1980, 35, 157-161.

Degueurce F., Abrous M., Dreyfuss G., Rondelaud D. \& Gevrey J. Paramphistomum daubneyi and Fasciola hepatica: the prevalence of natural or experimental infection in four species of freshwater snails in eastern France. Journal of Helminthology, 1999, 73, 197-202.

Diaz P., Paz-Silva A., Sánchez-Andrade R., Suárez J.L., Pedreira J., Arias M., Diez-Baños P. \& Morrondo P. Assessment of climatic and orographic conditions on the infection by Calicophoron daubneyi and Dicrocoelium dendriticum in grazing beef cattle (NW Spain). Veterinary Parasitology, 2007, 149, 285-289.

Dorchies P., LeVAsseur G. \& Alzieu J.P. La paramphistomose bovine : une pathologie d'actualité. Comptes rendus du Congrès de la Société Française de Buiatrie, Paris, 15-17 novembre 2000, 132-142.

Dorchies P., Bergeaud J.P., Duranton C., Prevot F. \& Tessier P. Extension de la paramphistomose bovine en France : résultats d'une enquête coproscopique sur 465 bovins dans treize départements. Revue de Médecine Vétérinaire de Toulouse, 1998, 149, 1029-1032.

Duffy T., Kleiman F., Pietrokovsky S., Issia L., Schijman A.G. \& Wisnivesky-Colli C. Real-time PCR strategy for rapid discrimination among main lymnaeid species from Argentina. Acta Tropica, 2009, 109, 1-4.

Mas-Coma S., Valero M.A. \& Bargues M.D. Fasciola, lymnaeids and human fascioliasis, with a global overview on disease transmission, epidemiology, evolutionary genetics, molecular epidemiology and control. Advances in Parasitology, 2009, 69, 44-146.

Mera y Sierra R., Artigas P., Cuervo P., Deis E., Sidoti L., MAs-Coma S. \& BARgues M.D. Fascioliasis transmission by Lymnaea neotropica confirmed by nuclear rDNA and mtDNA sequencing in Argentina. Veterinary Parasitology, 2009, 166, 73-79.

Nascimento C.C. Do, Nascimento A.A. DO, Mapeli E.B., Tebaldi J.H., Duarte J.M. \& Hoppe E.G. Natural infection by Paramphistomoidea Stiles and Goldberger, 1910 trematodes in wild Marsh Deer (Blastocerus dichotomus Illiger, 1815) from Sérgio Mottas's hydroelectric power station flooding area. Revista Brasileira de Parasitologia Veterinária, 2006, 15, 133-137.

OlLERENSHAW C.B. Some observations on the epidemiology of fascioliasis in relation to the timing of molluscicide applications in the control of the disease. The Veterinary Record, 1971, 88, 152-164.

Ozdal N., Gul A., Ilhan F. \& Deger S. Prevalence of Paramphistomum infection in cattle and sheep in Van Province, Turkey. Helminthologia, 2010, 47, 20-24. 
Pacenovsky J., Zahor Z. \& Krupicer I. First report of Paramphistomum daubneyi in cattle in Algeria. Veterinarni Medicina, 1987, 32, 379-384.

Rondelaud D., Fousi M., Vignoles P., Moncef M. \& Dreyfuss G. Optimization of metacercarial production for three digenean species by the use of Petri dishes for raising lettuce-fed Galba truncatula. Parasitology Research, 2007, $100,861-865$.

Rondelaud D., Vignoles P. \& Dreyfuss G. La Limnée tronquée, un mollusque d'intérêt médical et vétérinaire. PULIM, Limoges, 2009, 285 p.

SAnabria R., Moré G. \& Romero J. Molecular characterization of the ITS-2 fragment of Paramphistomum leydeni (Trematoda: Paramphistomidae). Veterinary Parasitology, 2011a, 177, 182-185.

Sanabria R., Moré G. \& Romero J. Paramphistomum leydeni: experimental infections in lambs and characterization of the rDNA ITS markers from flukes and snails. Proceedings of the $23^{\text {rd }}$ International Conference of the World Association for the Advancement of Veterinary Parasitology, Buenos Aires, 21-25 August 2011, C, 2011b, 23.

Sanabria R., Mouzet R., Pankrác J., Djuikwo Teukeng F.F., Courtioux N., Novobilský A., Höglund J., RašnÝ M., Vignoles P., Dreyfuss G., Rondelaud D. \& Romero J. Lymnaea neotropica and Lymnaea viatrix, potential intermediate hosts for Fascioloides magna. Journal of Helminthology, 2012, in press.

Seck M.T., BÂ C.T. \& Marchand B. Présence de Paramphistomum daubneyi Dinnik, 1962 (Digenea, Paramphistomidae, Trematoda) au Sénégal. Revue d'Élevage et de Médecine Vétérinaire des Pays Tropicaux, 2008, 61, 181-184.

SEY O. Life-cycle and geographical distribution of Paramphistomum daubneyi Dinnik, 1962 (Trematoda: Paramphistomata). Acta Veterinaria Academiae Scientiarum Hungaricae, 1979, 27, 115-130.

SEY O. Revision of the amphistomes of European ruminants. Parasitologica Hungarica, 1980, 13, 13-25.

Silvestre A., Sauve C. \& CABARET J. Caprine Paramphistomum daubneyi (Trematoda) infection in Europe. The Veterinary Record, 2000, 23, 674-675.

Vignoles P., Rondelaud D. \& Dreyfuss G. Paramphistomum daubneyi: production dynamics and infectivity of metacercariae originating from snails dissected at regular intervals. Journal of Helminthology, 2008, 82, 175-180.

Received on May $5^{\text {th }}, 2012$ Accepted on July 30 ${ }^{\text {th }}, 2012$ 